\title{
"Em estado de memória": a inscrição do trauma e as permanências de emoções dolorosas na obra da escritora argentina Tununa Mercado
}

\author{
Fábio Ávila ARCANJO D \\ Universidade Federal de Minas Gerais (UFMG)
}

\section{○}

OPEN ACCESS

EDITADO POR

- Glaucia Muniz Proença Lara (UFMG)

- Marluza da Rosa

(UFSM)

- Isabelle Tauzin-Castellanos (UBMontaigne)

\section{AVALIADO POR}

- Magda Santiago (UNA)

- Amanda Scherer (UFSM)

\section{DATAS}

- Recebido: 14/09/2021

- Aceito: 28/10/2021

- Publicado: 07/12/2021

\section{COMO CITAR}

Arcanjo, F.A. (2021). "Em estado de memória": a inscrição do trauma e as permanências de emoções dolorosas na obra da escritora argentina Tununa Mercado. Revista da Abralin, v. 20, n. 3, p. 158-172, 2021.
RESUMO

Este artigo objetiva analisar o livro Em estado de memória - escrito por Tununa Mercado e publicado, pela primeira vez, no ano de 1990 -, cujo enfoque gira em torno dos truncamentos de uma memória atravessada pela angústia do exílio, que irrompe em dois movimentos: a saída da pátria e o retorno, que trazem como consequência o esfacelamento identitário. O desenvolvimento da escrita será pontuado, em primeiro lugar, pelas noções de rememoração testemunhal e trauma, desenvolvidas por Seligmann-Silva (2003) e Cangi (2003), além das contribuições de Kristeva (1994), que pensa a figura do exilado como alguém que se vê constantemente ameaçado e tragado por lembranças de felicidades efêmeras e desastres vivenciados. Em segundo lugar, lidar-se-á com a mobilização das emoções, problematizadas por Lima (2016), com especial destaque para as categorias da melancolia e da nostalgia, partindo do princípio de que elas se configuram como efeitos de sentido proeminentes nos relatos de $\mathrm{Tu}-$ nuna Mercado. Constata-se que tanto a saída forçada quanto o retorno se configuram em acontecimentos traumáticos, que deixam marcas na materialidade discursiva. Para o livro de Tununa Mercado, o gesto de leitura adotado é de que tais marcas encontram ressonância na inscrição das emoções, com destaque para a nostalgia e para a melancolia. 


\section{REVISTA DA ABRALIN}

\section{ABSTRACT}

This article aims to analyze the book In a state of memory - written by Tununa Mercado and published, for the first time, in 1990 -, whose focus is on the truncation of a memory crossed by the anguish of exile, which erupts in two movements: the exit of the homeland and the return, that brings as a consequence the disintegration of identity. The development of writing will be marked first by the notions of testimonial remembrance and trauma developed in Seligmann-Silva (2003) and Cangi (2003), besides the contributions of Kristeva (1994), who thinks the figure of the exiled as someone who sees himself constantly threatened and swallowed by memories of ephemeral happiness and disasters experienced. Secondly, the article will deal with the mobilization of emotions, problematized by Lima (2016), with special emphasis on the categories of melancholy and nostalgia, assuming that they are configured as prominent effects of meaning in the report of Tununa Mercado. It is observed that both the expulsion and the return are configured as traumatic events, which leave marks in the discursive materiality. For the book by Tununa Mercado, the reading gesture adopted is that such marks find resonance in the inscription of emotions, especially nostalgia and melancholy.

\section{PALAVRAS-CHAVE}

Exílio. Testemunho. Trauma. Emoções.

\section{KEYWORDS}

Exile. Testimony. Trauma. Emotions.

\section{Introdução}

Em estado de memória é a tradução literal do título original da obra de Tununa Mercado, publicada pela primeira vez no ano de 1990. Nesse aspecto, as duas línguas (espanhol e português), mostramse bastante próximas - diferenciadas, na verdade, por apenas uma letra (En estado de memoria). Mas não é apenas isso (a familiaridade linguística), que aproxima as línguas portuguesa e espanhola, como mostra a realidade latino-americana. Tanto a Argentina quanto o Brasil compartilham uma fissura em suas histórias ao longo do século XX: a emergência de regimes ditatoriais, de vieses autoritários.

A exemplo do Brasil (1937-1945 - Estado Novo de Getúlio Vargas - e 1964-1985 - ditadura militar), a Argentina enfrentou regimes antidemocráticos, apoiados, segundo Vitale (2015), por memórias 


\section{REVISTA DA ABRALIN}

retórico-argumentais ${ }^{1}$ golpistas. Em Vitale (2015), encontramos uma problematização a respeito dos sucessivos golpes militares que aconteceram em seu país, entre o período de 1930-1976. A pesquisadora observa que a formulação desses regimes políticos autoritários acontece em meio à mobilização de dois tipos de memórias retórico-argumentais: golpista liberal (contra Hipólito Yrigoyen, em 1930; e contra Juan Domingos Perón, em 1955) e golpista nacionalista antiliberal (contra Ramón Castillo, em 1943; contra Arturo Umberto Illia, em 1966; e contra Maria Estela Martínez de Perón, em 1976).

A questão que se coloca, ao analisar esses fatos históricos, é atinente à instabilidade política e como ela impacta, decisivamente, a vida das pessoas que vivem nessa verdadeira "panela de pressão". A escritora Tununa Mercado está entre essas pessoas, tendo vivenciado dois exílios. O primeiro aconteceu entre os anos de 1966 e 1970, na França; e o segundo, de 1974 a 1986, no México. Resgatemos as palavras da autora:

Fui, por exemplo, ao "primeiro exílio" antes de completar 27 anos, regressei pouco antes de completar 31, fui embora de novo aos 34 e voltei aos 47. As épocas voaram como tornados, criando em mim, estados repentinos de confusão sobre a passagem do tempo (MERCADO, 2011, p. 75).

No excerto anterior, faz-se evidenciado um dos componentes prementes da experiência do exílio: o alheamento em relação ao tempo. Isso se dá em função de uma condição de proscrição, que traz como consequência a emergência de feridas consequenciais à agonia de ser expulsa da sua pátria e, ulteriormente, de não se enquadrar, plenamente, no local de destino. Há, destarte, o estabelecimento de um entre-lugar, que dificulta a inserção desse sujeito em um tempo, digamos, cronológico. Notemos uma passagem que corrobora essa ideia: "O tempo do exílio tem o trajeto de um grande traço [...]. Provisório, o tempo vai de semana a semana em um trem de paradas sucessivas" (MERCADO, 2011, p. 34).

Diante do que foi apresentado, este artigo será desenvolvido a partir de dois tópicos, com o objetivo de entender as ferramentas discursivas mobilizadas por Tununa Mercado para a escrita de Em tempo de memória. Em primeiro lugar, lidaremos com o entrecruzamento de três categorias, a saber, a rememoração, o testemunho e o trauma. Amparados em Ricoeur (2007), partimos do princípio de que o testemunho é uma encenação discursiva oferecida por aquele(a) que vivenciou os acontecimentos. É daí que vem o conceito de rememoração testemunhal, uma atividade aporética fundamentada em um campo de forças travado entre o dever de memória (2007) ou, falando como Claude Lanzmann, o dever de transmissão dos retornantes (2011) - e os travamentos, truncamentos, lapsos e hesitações originários do atravessamento do trauma.

O segundo tópico diz respeito aos efeitos de sentido mobilizados pela rememoração testemunhal de Tununa Mercado. Nesse particular, nossa atenção se voltará para a inscrição das emoções, que se mostram proeminentes no fio do discurso literário contemplado em nosso empreendimento,

\footnotetext{
${ }^{1}$ Noção "que considera en la palabra argumentativa no solo el tiempo breve del acontecimiento, sino [...] larga duración, o, al menos, un tiempo médio que exceda la fugacidade del acontecimiento" (VITALE, 2015, p. 8). No entendimento da autora, as memórias retórico-argumentais estão integradas a um éthos configurado nos discursos fundadores de 1930, que são retomados como forma de legitimação nas posteriores quebras do sistema democrático.
} 


\section{REVISTA DA ABRALIN}

lembrando, claro, que não estamos lidando diretamente com a recepção, (embora saibamos da importância de pesquisas desse tipo), mas com os efeitos de sentido mobilizados pela escritora argentina. Nesse tópico, direcionaremos nosso olhar para algumas categorias basilares, tais como: melancolia (Hersant, 2020); nostalgia (Rauchs, 2013); perlaboração (Robin, 2016); tristeza (Maisonneuve, 1969); e luto (Freud, 2011).

\section{A rememoração testemunhal e o atravessamento do trauma}

Em linhas anteriores, apresentamos um dos principais pressupostos para o entendimento do discurso testemunhal - a presença obrigatória da tríade dêitica eu estava lá. É pertinente notar a dinâmica existente entre o sujeito que vivenciou a experiência do exílio, com esse mesmo sujeito, em futuridade, enunciando tal acontecimento, configurando o eu, aqui e agora, que retorna ao passado de dor e de angústia. O que há entre essas duas tríades dêiticas? Qual seria o saldo existente entre o sujeito-que-vivenciou e o sujeito-que-narra? Alguns elementos se fazem presentes, tais como os travamentos, as emoções e, claro, o trauma.

Adjetivamos, na introdução do artigo, a rememoração testemunhal como sendo uma atividade aporética e isso se deve, conforme apontamos, pela conjugação da necessidade com a interdição, que se configura como o principal desafio para aquele que se propõe a rememorar suas vivências traumáticas. A questão que se coloca é: o que é testemunhado? Eis uma possível chave de resposta: "testemunha-se um excesso de realidade e o próprio testemunho enquanto narração testemunha uma falta: a cisão entre a linguagem e o evento, a impossibilidade de recobrir o vivido (o 'real') com o verbal" (SELIGMANN-SILVA, 2003, p. 46).

Há duas relações importantes com a linguagem a serem pensadas. Em primeiro lugar, voltando o olhar para o ato da rememoração, o que temos é uma impossibilidade de esgotamento. Seligmann-Silva (2003) indica a existência de algo situado na ordem do inimaginável. O autor fala da experiência concentracionária - mas podemos igualmente pensar no exílio -, que desconstrói aquilo que ele nomeia de "maquinário da linguagem", sendo o trauma um elemento atravessador que opera essa desconstrução.

Seligmann-Silva (2003) destaca que a rememoração testemunhal, circunscrita ao gênero literatura de testemunho, entrecruza duas variantes nem sempre harmônicas, uma vez que estamos lidando com um acontecimento traumático: a construção narrativa e o mundo fenomênico. Para o pesquisador, existem dois pontos centrais concernentes a esse tipo de escrita: uma relação e um tipo de compromisso com o "real", e o fato de que esse "real" deve "ser compreendido na chave freudiana do trauma, de um evento que justamente resiste à representação" (SELIGMANN-SILVA, 2003, p. 373). 


\section{REVISTA DA ABRALIN}

Outro elemento pertinente, já que, na citação anterior, há uma menção explícita ao postulado teórico desenvolvido por Freud, é a experiência do luto. A nosso ver, ela se inscreve na medida em que as vivências são expostas, ultrapassando as barreiras que funcionam como entrave para acionar esse "compromisso com o real"; seria uma das etapas de convivência com as cicatrizes consequenciais de um passado que insiste em não passar.

Então, em que consiste o trabalho realizado pelo luto? Creio que não é forçado descrevê-lo da seguinte maneira: a prova de realidade mostrou que o objeto amado já não existe mais e agora exige que toda libido seja retirada de suas ligações com esse objeto. Contra isso se levanta uma compreensível oposição: em geral se observa que o homem não abandona de bom grado uma posição da libido, nem mesmo quando um substituto já lhe acena. Essa posição pode ser tão intensa que ocorre um afastamento da realidade e uma adesão ao objeto por meio de uma psicose alucinatória de desejo (FREUD, 2011, p. 49).

Esse afastamento da realidade mencionado por Freud (2011) afigura-se na concepção de um trabalho de luto em desenvolvimento, atravessado por todas as dificuldades originárias daquilo que reside em um passado irrecuperável e inalcançável. Freud observa o potencial êxito obtido pelo respeito à realidade, embora ele ressalte que isso é decorrência de um processo marcado pela lentidão. O senso comum sintetizaria essa asserção com uma expressão deveras conhecida: "é preciso dar tempo ao tempo", o que, de acordo com o autor, ocorre

(...) com grande dispêndio de tempo e energia de investimento, e enquanto isso a existência do objeto de investimento é psiquicamente prolongada. Uma a uma, as lembranças e expectativas pelas quais a libido se ligava ao objeto são focalizadas e superinvestidas e nelas se realiza o desligamento da libido (FREUD, 2011, p. 49).

Há uma razão especial para trazer esses fragmentos extraídos da clássica obra freudiana Luto $e$ melancolia. Para compreender a rememoração testemunhal, é mister levar em consideração a existência da perda, da angústia e da dor, que trazem consigo as recorrências do trauma, em meio a uma vida que precisa, para tentar seguir em frente, trabalhar esse luto. Tununa Mercado tem consciência disso, acreditando que a psicanálise, e com ela a possibilidade de elaborar verbalmente suas inquietações e ansiedades, ajudaria em sua batalha, a despeito de ela não ter conseguido um desejável tratamento individualizado. Vejamos o que a escritora nos fala:

\footnotetext{
Em termos terapêuticos estritos, a psicanálise sempre me foi poupada. Nunca, para dizer a verdade, pude recorrer a um tratamento clínico individual em que eu oferecesse, na horizontal, os materiais de meu inconsciente, sempre, por razões econômicas, tive de frequentar terapias de grupo, nas quais, sem maior esforço, consegui escamotear dos olhos dos meus companheiros, e talvez da sagacidade da minha psiquiatra, minha angústia e minha vulnerabilidade (MERCADO, 2011, p. 14-15).
}

Em seguida, Tununa Mercado fala-nos dos subterfúgios acionados para lidar com os sofrimentos do passado que se inscrevem no presente - risadas, prantos coletivos e um bom senso que se confunde com a amargura. O curioso é que, em uma passagem do livro, a escritora revela um conselho oferecido por uma amiga, segundo a qual uma boa possibilidade de elaboração desse trauma poderia ser através da escrita. Tununa Mercado, ao receber tal conselho, o desconsiderou, por enfrentar, 


\section{REVISTA DA ABRALIN}

naquele instante, um estado de ensimesmamento, sentindo-se "desgraçada e miserável [e] querendo fugir o quanto antes e à beira das lágrimas" (MERCADO, 2011, p. 69). Se, naquele momento, o conselho da amiga foi interpretado como falta de sensibilidade (Tununa Mercado não queria um conselho, mas apenas conversar com alguém), em futuridade ele parece ter surtido algum tipo de efeito.

O segundo ponto relacionado à linguagem diz respeito à própria experiência do exílio. A saída forçada do seu lugar de origem, a necessidade de se afastar obrigatoriamente das raízes de sua formação identitária e, consequentemente, de se deparar com novas conjunturas e desafios - essa é a vida do expatriado, na batalha para lidar com aflições geradoras de traumas futuros, cujos sinais iniciais são percebidos na linguagem. No primeiro exílio (entre os anos de 1966 e 1970), Tununa Mercado partiu para a França, sem falar a língua local. É de se imaginar que tal realidade traz consigo a solidão, em um quadro já desconfortável - preocupação com as pessoas que ficaram e dificuldade de adaptação, em função não só da barreira da língua, mas também da nova realidade que se apresenta. Julia Kristeva identifica esse mecanismo de ruptura como silêncio dos poliglotas:

Não falar a sua língua materna. Habitar sonoridades e lógicas cortadas da memória noturna do corpo, do
sono agridoce da infância. Trazer em si como um jazigo secreto ou como uma criança deficiente - ben-
quista e inútil - essa linguagem de outrora que murcha sem jamais abandoná-lo (KRISTEVA, 1994, p. 22).

Nessa citação, notamos como a linguagem configura-se em caráter identitário do ser humano, isto é, ela nos constitui, formando o nosso imaginário, nossas crenças e nossos valores. Há uma dualidade bem marcada no fragmento: a infância agridoce vs. um jazigo secreto e inócuo. O ponto de contato entre essa contraposição é, justamente, a língua materna: viva e vibrante na infância; morta (a referência ao jazigo não é fortuita) e inútil na vivência do exílio.

Levando em consideração a jornada de Tununa Mercado, há uma particularidade ainda mais instigante, principalmente em relação ao segundo exílio, entre os anos de 1974 e 1986. O destino da escritora foi o México, país que, como sabemos, compartilha da mesma língua oficial adotada pela Argentina. Isso posto, uma análise apressada levaria à conclusão de que o silêncio dos poliglotas, apresentado por Julia Kristeva, não encontra ressonância nessa segunda experiência de afastamento abrupto da pátria. Mas a obra Em estado de memória desmente essa impressão:

\footnotetext{
Às vezes, obrigavam-se à humildade de eliminar o uso do che e do tratamento por "vos", então, permaneciam mediocrizados em cultismos do espanhol a que resistiam e que não se moldavam aos modos portenhos dos quais raramente se pode sair, por serem marcados em demasia. Chegavam a assumir, inclusive, certas humilhações linguísticas, como a substituição do che arrugado e gingado de Buenos Aires por uma espécie de ie que, com tanta facilidade, soltam as pessoas de Córdoba até o norte e que nos lábios dos portenhos, é extremamente desmedida, porque não chega a plasmar-se e, quando acredita ter conseguido, em nada se parece ao ie dos mexicanos e menos ainda ao che (MERCADO, 2011, p. 40).
}

O que importa destacar, e é isso que a escritora parece fazer, não é o juízo de valor a respeito de determinadas variações linguísticas. O mesmo movimento de estranhamento pode ser traçado na inversão de papéis - caso, por exemplo, um mexicano precise se exilar na Argentina (a artificialidade estaria migrada para o che). O que temos é a constatação de um quadro antinatural. Vale destacar, 


\section{REVISTA DA ABRALIN}

contudo, a diferença entre um turista argentino no México e um exilado. O primeiro, caso queira utilizar a variação mexicana, padecerá de uma artificialidade, mas não haverá um desconforto traumático, pois, em breve, ele poderá utilizar o che, sem maiores implicações. O segundo, por outro lado, está em terra estrangeira, sem saber quando voltará para casa. Está, dessa forma, em um entrelugar, distanciado tanto da variação linguística mexicana, quanto da variação argentina.

Até o momento, apresentamos questões relacionadas às dificuldades enfrentadas no exílio e como a rememoração testemunhal dessas vivências é atravessada pela impossibilidade conjugada com a necessidade. Entretanto, nos deparamos com uma pergunta pertinente: o simples retorno à pátria facilitaria a vida? O fato de existirem permanências das angústias e a inevitabilidade de trabalhar o luto, indica que facilidade é um termo acentuadamente distante para caracterizar a trajetória dos deportados no retorno para "casa".

Em uma passagem de seu livro, a escritora argentina relata com bastante acidez o desejo vão de seus compatriotas em tentar levar, ao término do exílio, alguns rituais e costumes próprios do México. É curioso notar como ela se coloca em vista desse movimento, sendo a escolha lexical para caracterizá-lo algo que pontua o seu estado de espírito: pena, impaciência, tédio e cansaço. Tununa Mercado observa que esses rituais desnaturalizados, na Argentina, produzem dois elementos próprios do trauma do exílio: estranhamento e nostalgia. "Sentimo-nos um pouco bobos por acreditar que esses pequenos rituais de acomodamento no solo argentino vão nos salvar do estrondo da identidade perdida" (MERCADO, 2011, p. 42).

Há um desdobramento no sofrimento daquele que é tido como indesejado diante do modus operandi instaurado por determinados aparatos repressores de Estado. O prólogo da angústia começa em seu próprio país, com as perseguições, a cassação de direitos e o desaparecimento, seguidos pela morte de companheiros de luta. Ulteriormente, em virtude da saída forçada, temos as vivências do exílio, com as dificuldades de adaptação e, claro, a saudade da pátria. A filósofa francesa Barbara Cassin ilustra bem as perdas enfrentadas pelos exilados: "Nós perdemos a nossa casa, a familiaridade da nossa vida quotidiana [...], mas, sobretudo, perdemos a nossa língua materna, ou seja, as nossas reações naturais, a simplicidade dos gestos e a expressão espontânea dos nossos sentimentos ${ }^{2 "}$ (CASSIN, 2013, p. 99, tradução nossa). Por fim, temos o retorno traumático, que, de alguma forma, ratifica o esfacelamento da identidade, como bem indica o último excerto extraído da obra de Tununa Mercado.

É por intermédio desse equacionamento de acontecimentos traumáticos, em futuridade, que a rememoração testemunhal se inscreve, raciocinando a partir do saldo existente entre o sujeito que estava lá e o sujeito no momento de enunciação dessas memórias. Adrian Cangi pontua que

somente a testemunha pode fazer advir o passado como segredo do instante gélido que habita seu corpo, como se de um illo tempore se tratasse. Cada gesto da testemunha pronuncia um testemunho

\footnotetext{
${ }^{2}$ No original : "Nous avons perdu notre foyer, la familiarité de notre vie quotidienne [...], mais surtout nous avons perdu notre langue maternelle, c'est à dire nos réactions naturelles, la simplicité des gestes et l'expression spontanée de nos sentiments".
} 


\section{REVISTA DA ABRALIN}

na ausência deste. Esse silêncio é uma marca engendrada pelo horror da razão que desencadeou a loucura na palavra (CANGI, 2003, p. 159-160).

Diante do exposto, as palavras de Cangi nos impelem a reconhecer que a rememoração testemunhal se constitui como um ato de resistência, ato esse que precisa equacionar algumas construções verbais: fazer-lembrar para, consequentemente, fazer-interditar eventuais novas tentativas de ruptura democrática, pois, como afirma Primo Levi, "muitos novos tiranos guardam nas gavetas o Mein Kampf de Adolf Hitler: talvez com algumas retificações ou certas substituições de nomes, pode ainda ser oportuno" (LEVI, 2004, p. 174). Façamos uma paráfrase da citação anterior, aventando o potencial surgimento de novos tiranos, que guardam em suas gavetas manuais de conduta adotados pela junta militar argentina ou, em âmbito brasileiro, que celebram os feitos de nomes como Carlos Alberto Brilhante Ustra ${ }^{3}$.

\section{A rememoração testemunhal e a inscrição das emoções}

No tópico anterior, lidamos com o postulado, segundo o qual entre o sujeito-que-vivencia e o sujeito-que-rememora existe um saldo comumente preenchido pelo trauma, já que estamos lidando com um acontecimento cuja implicação é o esfacelamento da identidade daqueles que sofreram seus impactos. Nesse tópico, falaremos de outra categoria - o pathos (mobilização das emoções) -, engendrada por intermédio desse saldo e que confere potência narrativa (definindo, por assim dizer, a rememoração testemunhal) de forma ainda mais marcada. Contudo, não nos enganemos: não há, aqui, uma tentativa de comparar categorias, até mesmo porque, o que aciona as emoções no fio do discurso é, justamente, a experiência traumática. Explicando melhor: as emoções conferem tom aos relatos, sendo impulsionadas pelas permanências da dor.

Convém observar que o trabalho de luto se vincula, diretamente, com a noção de perlaboração que, grosso modo, seria um movimento de aceitação, ou, quiçá, um acolhimento de uma vivência marcada pela angústia. A pesquisadora francesa Régine Robin assevera que "o passado perlaborado, submetido ao trabalho de luto, não é uma lembrança revivida tal e qual, mas um passado trabalhado na e pela transferência, que passa a ser 'aceitável' pelo sujeito" (ROBIN, 2016, p. 34). Há, e o fragmento anterior é enfático, uma impossibilidade de reconstituição plena: não se trata de uma lembrança revivida integralmente, mas, sim, de uma espécie de resto, que emerge em meio aos travamentos, atos falhos e esquecimentos, conferindo ressonância para a manifestação das emoções.

\footnotetext{
${ }^{3}$ Primeiro militar condenado judicialmente pela prática de tortura durante a ditadura militar, Carlos Alberto Brilhante Ustra chefiou o órgão de repressão DOI-CODI, em São Paulo, entre os anos de 1970 e 1974. É considerado o principal torturador do regime ditatorial vigente no Brasil entre os anos de 1964 e 1985. Fonte: http://g1.globo.com/distrito-federal/noticia/2015/10/morre-brilhante-ustra-ex-chefe-de-orgao-de-repressao-na-ditadura.html.
} 


\section{REVISTA DA ABRALIN}

O exílio aparece-me como um enorme mural riveriano, com protagonistas e comparsas, líderes e bufões, vivos e mortos, doentes e despossuídos, corroídos e corrompidos; o mural tem uma espessa cor plúmbea, e seus traços são grossos. Há um forte dissabor na evocação; esforço-me, neste momento, para separar do conjunto algum instante coletivo da felicidade, porque estes existiram, mas a melancolia leva a dianteira, nada se subtrai à melancolia de uma recordação cinza, mesmo que muito intensa (MERCADO, 2011, p. 33).

Há algumas questões, expostas no excerto antecedente, que merecem ser problematizadas. Em primeiro lugar, temos uma explícita contraposição: felicidade vs. melancolia. A autora não nega a existência de momentos felizes, contudo o caráter cinzento do exílio confere primazia à melancolia. Para alguém alheio às vivências da escritora argentina, esse primado da melancolia pode ser considerado uma radicalidade. Contudo, estamos diante de situações-limite, sedimentadas em meio a deslocamentos traumáticos, que esfacelam identidades. Existe, portanto, um distanciamento entre sujeitos que vivenciam o trauma e potenciais leitores de experiências traumáticas. Assim sendo, "as emoções são essenciais [...], pois é através delas que as distâncias são negociadas. A identidade dos grupos é constituída pelos valores que são comuns aos sujeitos e os transcendem também" (LIMA, 2016, p. 252).

É salutar, inicialmente, notar que Lima faz menção à definição de retórica desenvolvida por Meyer (2007), segundo a qual, o saldo distanciador entre os indivíduos e a negociação dessa distância, em uma questão dada, definem uma enunciação retórica. Como entender isso no último fragmento destacado da obra de Tununa Mercado? O ato de narrar e perlaborar o seu passado mobiliza a emergência das emoções. De certa forma, um dos elementos que diferencia o exilado de seu potencial público (aquele que se prontifica a acessar sua rememoração testemunhal) são as emoções consequenciais ao reavivamento do passado traumático. Na passagem referenciada, temos a presença de uma emoção dita, passível de ser experienciada por outras pessoas. Mas nesse contexto, ela está relacionada ao exílio, sendo uma particularidade na vida dos desterrados.

É constatável o fato de estarmos diante de uma manifestação individual. O que está em jogo são as vivências de Tununa Mercado, ou seja, há uma projeção da memória individual; contudo, e isso nos parece central, há um componente de partilha, no sentido de as emoções serem sociais e coletivas. A melancolia, possivelmente, foi experienciada por outros exilados, pois eles compartilham valores que lhes foram retirados: a pátria e a língua materna. Daí a ideia de esfacelamento identitário, cujo efeito de sentido operacionalizado no fio do discurso se dá pela projeção das emoções.

A melancolia acaba sendo o resultado de uma falta, de um valor compartilhado e ulteriormente afastado da vivência cotidiana. Essa é uma distância a ser negociada, pela linguagem, entre Tununa Mercado e o leitor, para que ele possa dimensionar aquilo que foi narrado. Conforme nos alerta Seligmann-Silva (2012), ao prefaciar a tradução em língua portuguesa do testemunho de Pierre Seel ${ }^{4}$, a rememoração testemunhal é coletiva e política, e o leitor precisa adentrar essa cena de testemunho para que haja uma diminuição das distâncias entre autor e leitor e, ulteriormente, para que os relatos

\footnotetext{
${ }^{4}$ Único deportado francês, abertamente homossexual, a relatar suas vivências nos campos de concentração. A deportação de Seel para o campo de Schirmeck-Vorbrüch foi uma consequência direta de sua orientação sexual. Seu testemunho foi registrado no livro Eu, Pierre Seel, deportado e homossexual, lançado no ano de 1994.
} 


\section{REVISTA DA ABRALIN}

contribuam na conscientização de que tais acontecimentos não podem adentrar novamente a história de um país.

Um ponto que se mostra fundamental, perante o exposto, é a definição de melancolia. Yves Hersant (2020) destaca "a prodigiosa diversidade das manifestações melancólicas: agressividade e ensimesmamento, acabrunhamento e entusiasmo, culpabilidade e desejos loucos, lamúria e desprezo, ideias fixas e loucas, quimeras..." (HERSANT, 2020, p. 461). Constata-se, destarte, que não estamos lidando com uma emoção específica, mas, sim, com uma miríade de emoções. Hersant (2020), inclusive, evoca Hipócrates e seus aforismos, segundo o qual, a bílis negra (melancolia) seria o resultado de uma permanência do medo (phóbos) e da tristeza (dysthymia).

Alguns sintomas são destacados pelo pesquisador francês, lembrando que o uso do item lexical sintomas, não é fortuito, já que, inicialmente, a melancolia foi problematizada no âmbito da medicina: medo da finitude, desespero amoroso e desprezo de viver. O que se constata, a partir da proliferação de sintomas, impeditivos de uma classificação estanque, é que "a melancolia excede o domínio médico no qual ela nasceu. Entre a loucura e as afeições de todos os dias, ela mantém um continuum; em seu grau mais fraco ela pode nos roubar o sol, e é ela ainda que em seu grau mais intenso pode fazer naufragar nossa razão" (HERSANT, 2020, p. 461-462; grifo do original). Apresentemos uma significativa passagem de Em tempo de memória:

\footnotetext{
Passei minha vida nesse compartimento de minha pessoa, no qual nele sempre é noite, e a sucessão do negro ao cinza indica os tempos inativos, à espera da luz. Esta anuncia-se, fazendo passar de um lado para o outro, de cima para baixo, de leste a oeste, de norte a sul e por todos os infinitos pontos cardeais intermediários de meu universo, valha a licença, centelhas brancas e brilhantes (MERCADO, 2011, p. 107-108)
}

Existe uma desesperança nas palavras de Tununa Mercado, figurativizada por uma luz que apenas a tangencia, já que as cores que prevalecem em sua vida são o cinza e o negro. Há, ainda, a descontinuidade temporal (o tempo inativo), caracterizadora do entre-lugar e de uma vida que se encontra paralisada, à espera de um devir que se apresenta na chave da impossibilidade. Julia Kristeva observa que, na vida do estrangeiro, isto é, do exilado, existe uma "felicidade cabisbaixa, de uma discrição medrosa, apesar de sua intrusão penetrante, pois o estrangeiro continua a se sentir ameaçado pelo território de outrora, tragado pela lembrança de uma felicidade ou de um desastre sempre excessivos" (KRISTEVA, 1994, p. 12).

Trazer à tona uma discussão sobre a melancolia implica, de forma quase inescapável, considerar as contribuições oferecidas por Freud, em seu já citado estudo O luto e a melancolia. Para o autor:

A melancolia se caracteriza por um desânimo profundamente doloroso, uma suspensão do interesse pelo mundo externo, perda da capacidade de amar, inibição de toda atividade e um rebaixamento do sentimento de autoestima, que se expressa em autorrecriminações e autoinsultos, chegando até a expectativa delirante de punição. Esse quadro se aproximará mais de nossa compreensão se considerarmos que o luto revela os mesmos traços, exceto um: falta nele a perturbação do sentimento de autoestima (FREUD, 2011, p. 47). 


\section{REVISTA DA ABRALIN}

Nas diversas passagens, extraídas de Em tempo de memória, constatamos os sinais observados na citação precedente. Destaquemos a intermitente sensação de desânimo e o alheamento em relação ao mundo externo que dialogam com essa percepção de um tempo inativo, isto é, suspenso, quase como se a pessoa que vivencia tais sintomas tivesse se transformado em um fantasma. Nas palavras de Kristeva, "não pertencer a lugar nenhum, nenhum tempo, nenhum amor. A origem perdida, o enraizamento impossível, a memória imergente, o presente em suspenso" (KRISTEVA, 1994, p. 15). A autora assevera que, para o estrangeiro, existe sempre uma sensação de ausência, caracterizando o "lugar" ocupado por ele como "um trem em marcha, um avião em pleno ar, a própria tra nsição que exclui a parada. Pontos de referência, nada mais. O seu tempo? O de uma ressurreição que se lembra da morte e do antes, mas perde a glória do estar além..." (KRISTEVA, 1994, p. 15).

É possível sair da melancolia? Eis uma questão de difícil resposta, ainda mais pelo fato de não estarmos vinculados ao campo da psicologia. Nosso foco, aqui, é lidar com efeitos de sentido suscitados na materialidade linguística. O que guia o nosso gesto de leitura é a obra testemunhal de Tununa Mercado. Em decorrência disso, torna-se ainda mais complexo encontrar essa resposta e, claro, detectar se a escritora experienciou a melancolia e, em caso afirmativo, se ela conseguiu superar a sua incursão nessa emoção. Mas uma questão a ser destacada, e quem o faz é Yves Hersant (2020), relaciona-se ao movimento de apreensão da saída da melancolia como uma afetação somente individual. A partir do século XVII, ela se torna coletiva, criando condições para se pensar em melancolias nacionais. Isso, em nosso entendimento, parece ter se agravado, ulteriormente, com os diversos conflitos de cunho nacionalista enfrentados pela Europa, culminando no século XX, um marco temporal repleto de diásporas, exílios e angústias, consequenciais a políticas de intolerância contrárias a determinados posicionamentos políticos, orientações sexuais e enquadramentos étnicos.

A despeito da impossibilidade de apreender plenamente a saída da melancolia, atestemos, com base na contraposição freudiana, que, embora existam pontos de contato, o trabalho de luto se configuraria em uma tentativa de refutar um potencial quadro melancólico. Esse trabalho de luto, conforme apontamos anteriormente, estaria ligado à perlaboração do passado, sendo um dos mecanismos para o seu alcance, justamente, a escrita, isto é, a colocação em cena de um dever de transmissão. Decorre daí, segundo Freud, a não perda da sensação de autoestima, algo que se faz presente na rotina do melancólico.

Entender a melancolia como uma miríade de emoções implica a compreensão dos gatilhos suscitadores desse quadro. Yves Hersant destaca, e isso foi salientado em linhas anteriores, elementos como medo da finitude, desespero amoroso e desprezo de viver. Voltemos o olhar para o último. A que se deve esse menosprezo pela vida? Como tal sentimento adentrou a vida do melancólico? Uma possível chave de resposta passa pela nostalgia.

O apego ao país que havíamos deixado condicionou a vida de todos nós; houve, inclusive, pessoas que não puderam superar a soma de perdas, que passavam o dia em seu bairro, idealizando práticas que não viam bem, porque tinham de ser consideradas paradigmáticas de um paraíso perdido. A substância argentina da qual se sentia saudades aparecia encarnada nessas mitologias de escasso interesse (MERCADO, 2011, p. 37-38). 


\title{
REVISTA DA ABRALIN
}

A exemplo da melancolia, a nostalgia foi taxada, durante um longo intervalo de tempo, como uma enfermidade. Em seu estudo sobre essa temática, Rauchs (2013) perpassa algumas etapas, construindo três grandes eixos: médico/psiquiátrico; poético/literário; e político. O início de seu olhar se dá no ano de 1569, a partir de um diagnóstico oferecido por um oficial chamado Ludwig Phyffer, segundo o qual um de seus subordinados estava sofrendo de mal do país. A nomenclatura Le mal suisse se justifica pelo espaço no qual se deu esse primeiro diagnóstico.

Existe uma inter-relação, uma espécie de deslizamento entre a nostalgia e a melancolia. A leitura de Em tempo de memória confirma a existência de uma dinâmica entre essas duas afecções, a ponto de podermos pensar em um mecanismo de causa e consequência. A melancolia, nesse ínterim, emerge como um gatilho para emoções, em especial a tristeza, sendo o resultado da saudade da pátria, ou nas palavras de Tununa Mercado, do "apego ao país que havíamos deixado".

\begin{abstract}
A nostalgia vê o passado em cor-de-rosa onde a melancolia, a irmã mais velha, vê o futuro sob a cor preta. Mas será que se sabe que cada uma dessas duas afecções tem sua origem no mundo médico? Desde Hipócrates, a melancolia designa a bílis negra, um dos quatro humores que constituem, na doutrina do mestre de Cós, o corpo humano. A palavra nostalgia, apesar de remeter ao grego antigo, aparece muito mais tarde: em 1688, um obscuro médico alsaciano, Johannes Hofer, inventa o que é então um neologismo para descrever uma doença mortal, causada pelo mal do país. Com o passar dos séculos, o lamento da pátria ausente torna-se mais rapidamente o apaziguamento de um passado irremediavelmente ultrapassado. O pesar do espaço ausente transformou-se, portanto, (também) em arrependimento do tempo perdido. E o improvável regresso à pátria faz eco com o impossível regresso à infância ${ }^{5}$ (RAUCHS, 2013, p. 15; tradução nossa).
\end{abstract}

Não cabe, nesse espaço, adentrar os meandros relacionados às diversas tratativas concedidas à nostalgia. O que nos parece instigante é perceber a conexão entre tal afecção (na forma como Paul Rauchs a caracteriza) e a melancolia. O ponto que se mostra fulcral em nosso gesto de análise é o resultado desse equacionamento. O outrora nomeado mal do país e a antiga bílis negra não seriam, em nossa concepção, emoções, mas, sim, miríades emocionais, que oferecem ressonâncias para emoções particularizadas, com destaque especial para a tristeza. Portanto, olhar para tais categorias significa perceber seus desdobramentos. Para o filósofo francês Jean Maisonneuve, "o sentido da tristeza baseia-se, antes, em uma intuição de valor. Essa intuição nos apresenta um acontecimento físico ou mental que nos afeta como uma perda, uma diminuição, que nos atinge no mais profundo do nosso ser" (MAISONNEUVE, 1969, p. 56; tradução nossa).

\footnotetext{
${ }^{5}$ No original: "La nostalgie voit le passé en rose là où la mélancolie, sa soeur aînée, voit l'avenir en noir. Mais sait-on seulement que ces deux affects tirent chacune leur origine du monde médical? Depuis Hippocrate, la mélancolie désigne la bile noire, l'une des quatre humeurs qui constituent dans la doctrine du maître de Cos, le corps humain. Le mot nostalgie, malgré son masque en grec ancien, apparait bien plus tard : en 1688, un obscur médecin alsacien, Johannes Hofer, invente ce qui est alors un néologisme pour décrire un maladie mortelle, causée par le mal du pays. Au fil des siècles, le regret de la patrie absente devient plus vite l'attendrissement sur un passé irrémediablement révolu. Le regret de l'espace absente s'est donc métamorphosé (aussi) en regret du temps perdu. Et l'improbable retour dans la patrie fait écho à l'impossible retour dans l'enfance".
}

${ }^{6}$ No original: "Le sens de la tristesse repose donc avant tout sur une intuition de valeur. Cette intuition nous presente l'événement psysique ou mental qui nous affecte comme une perte, une diminuition, qui nous atteignent au plus profond de nous-même". 


\title{
REVISTA DA ABRALIN
}

A tese que defendemos é de que a emoção da tristeza funciona como um saldo existente na inscrição de duas categorias mais abrangentes: a melancolia e a nostalgia, muito embora apenas tais categorias sejam constantemente enunciadas por Tununa Mercado. Vejamos que há um ponto de contato entre o que está expresso no texto de Maisonneuve (1969) e a definição de Lima (2016), que chama a atenção para a ideia de valor. Conforme mencionamos, reiteradas vezes, o valor mais profícuo na obra da escritora argentina é o de pátria, e quando ela se vê radicalmente afastada desse valor, o que entra em cena é uma espécie de cisão identitária.

\begin{abstract}
Nos novos pesadelos, erigiu-se a casa futura: sempre era inconclusa, os quartos sempre tinham portas que davam a outros recintos ainda inexplorados, mas que alguma vez seriam incorporados. Essa casa possível, mais além dos muros verdadeiros, crescia, convidando-me a percorrer os corredores escuros e a subir escadas, que, de repente, se partiam, como as galerias da própria existência. Então, os quartos ficavam isolados, fora de ordem e de série, mas eram atraentes, pois supúnhamos que neles estariam os objetos e os móveis perdidos (MERCADO, 2011, p. 142).
\end{abstract}

No fragmento anterior, estamos diante de uma projeção do espaço a ser novamente ocupado quando do retorno à terra natal. Como seria a nova casa? Como seria essa nova realidade? O que era evidente para a escritora, após treze anos afastada de Buenos Aires, era "que essa casa levava a evocar, além do mais, todas as casas anteriores que havíamos abandonado" (MERCADO, 2011, p. 142).

O que se apresenta é o constante sentimento de perda. A nostalgia e a melancolia não são originárias, exclusivamente, da saudade da pátria, mas sim de hábitos adquiridos, que envolvem, inclusive, as experiências do exílio. O desencadeador disso, certamente, é a saída forçada, mas com ela advém uma série de implicações e uma intermitente sensação de alheamento, a ser enfrentada pelo trabalho de luto. Há, consequentemente, dois desconfortos a serem combatidos: a saudade da pátria e, evocando Rauchs (2013), a desilusão do retorno.

Rauchs (2013) estabelece uma relação entre uma terminologia própria da psicanálise - o retorno do recalcado (lapsos e atos falhos) -, com o retorno do exilado. O pesquisador se pergunta: "o retorno do recalcado ecoaria a dor do retorno, tradução literária da nostalgia? É verdade que o retorno do recalcado se faz sempre na dor. Os poucos exilados que tiveram a (má?) chance de retornar [ao seu país de origem] a experimentaram" (RAUCHS, 2013, p. 227; tradução nossa).

Faz-se interessante evocar uma passagem do testemunho de Tununa Mercado, em que a autora relata a angústia sentida durante o voo para sua terra natal: "A primeira vez que vim à Argentina foi em 1984. Meu maior desejo era que o avião passasse direto, que não se detivesse em Ezeiza" (MERCADO, 2011, p. 78-79). A possibilidade de voltar para casa, portanto, não a empolgava, e as razões para isso são evidentes: qual o conceito de casa? Como entender essa ideia de casa? Na vida do exilado tal morada parece ser revestida de restos e espaços fluidos. Falando como Kristeva (1994, p. 15), trata-se de "um trem em marcha, um avião em pleno ar", ou seja, a vida residindo no deslocamento e no descolamento.

\footnotetext{
${ }^{7}$ No original: "le retour du refoulé ferait-il écho à la douleur du retour, traduction littéraire de la nostalgie? Il est vrai que le retour du refoulé se fait toujour dans la douleur. Les quelques exilés qui ont eu la (mal?) chance de revenir en ont fait l'expérience".
} 


\section{REVISTA DA ABRALIN}

O revestimento da "morada" do exilado se dá, conforme apontamos, em meio aos restos e espaços porosos. Mas e internamente? Esta metafórica morada, em nosso modo de entender, é composta, entre outros elementos não contemplados em nossa análise, pelas emoções, que se constituem em efeitos de sentido suscitados pela escritora argentina. É a partir daí que se percebe o engendramento de categorias como melancolia, nostalgia e tristeza, compondo o supramencionado trabalho de luto mobilizado por Tununa Mercado.

\section{Considerações finais}

Existem dois movimentos percorridos em nosso gesto de análise. Em primeiro lugar, levando em conta a materialidade discursiva, procuramos analisar aspectos atinentes à formulação da rememoração testemunhal engendrada por Tununa Mercado, tendo em mente um componente basilar - o atravessamento do trauma. A escrita configura-se, em vista disso, a contrapelo, buscando equacionar a impossibilidade (travamentos originários da experiência traumática) com a necessidade (o dever de transmissão). Partimos do princípio de que a escrita testemunhal é passível de ser lida como uma composição do trabalho de luto, que, na maioria das vezes, não consegue apagar plenamente as cicatrizes de uma ferida, oferecendo como consequência o esfacelamento identitário.

O segundo movimento, uma espécie de consequência dessa formulação turbulenta, está relacionado aos efeitos de sentido suscitados na rememoração testemunhal de Tununa Mercado. É aqui que entra em cena uma categoria premente na obra analisada: o páthos. Não temos a intenção de atestar que determinadas emoções foram sentidas por Tununa Mercado, mas, sim, detectá-las na materialidade do texto. A melancolia e a nostalgia são duas categorias que se fazem importantes na composição de Em tempo de memória, a despeito de não serem consideradas emoções singulares, mas, ao contrário, gatilhos emocionais (ao longo do texto, utilizamos a expressão miríade para caracterizá-las).

Em vista disso, estamos diante de um entrecruzamento de categorias que convergem na percepção de que a obra analisada gira em torno de uma experiência traumática, mobilizada pela tristeza, pela nostalgia e pela melancolia. É importante enfatizar que o presente artigo opera um gesto de leitura do procedimento de rememoração testemunhal, calcado na tentativa de compreender um trabalho de luto sistematizado, entre outras possibilidades não desenvolvidas em nosso texto, pela inscrição das emoções. Não objetivamos esgotar as diversas interpretações passíveis de emergirem. O que julgamos relevante é que outras leituras possam ser feitas, uma vez que há um caráter de presságio no texto de Tununa Mercado, muito embora estejamos falando de acontecimentos do passado. O fato é que a repetição dessas vivências está longe de ser interditada, já que existem, na contemporaneidade, sinais de retorno de sistemas autoritários, sedimentados em preconceitos e na intolerância. Essa talvez seja a grande importância de Em tempo de memória: conscientizar para, consequentemente, impedir a vigoração de valores distantes de estar apagados. 


\section{REVISTA DA ABRALIN}

\section{REFERÊNCIAS}

CANGI, A. Imagens do horror. Paixões tristes. In: SELIGMANN-SILVA, M. (Org.). História, memória e literatura: o testemunho na era das catástrofes. Campinas: Editora da Unicamp, 2003. p. 139-170.

CASSIN, B. La nostalgie: quand donc est-on chez soi? Ulysse, Énée, Arendt. Paris: Autrement, 2013.

FREUD, S. Luto e melancolia. Trad. Marilene Carone. São Paulo: Cosac Naify, 2011.

HERSANT, Y. A melancolia. Trad. Francisco Morás. In: VIGARELLO, G. (Org.). História das emoções - volume 1 (Da antiguidade às luzes). Petrópolis: Vozes, 2020. p. 461-483.

KRISTEVA, J. Estrangeiros para nós mesmos. Trad. Maria Carlota Carvalho Gomes. Rio de Janeiro: Rocco, 1994.

LANZMANN, C. A lebre da Patagônia. Trad. Eduardo Brandão e Dorothée de Bruchard. São Paulo: Companhia das Letras, 2011.

LEVI, P. Os afogados e os sobreviventes. Trad. Luiz Sérgio Henriques. São Paulo: Paz e Terra, 2004.

LIMA, H. As emoções e suas implicações na construção argumentativa. In: PIRIS, E. L. Moisés Olímpio-Ferreira, M. (Org.). Discurso e argumentação em múltiplos enfoques. Coimbra: Grácio Editor, 2016. v. 1, p. 241-259.

MAISONNEUVE, J. Les sentiments. Paris: PUF, 1969.

MERCADO, T. Em estado de memória. Trad. Idelber Avelar. Rio de Janeiro: Record, 2011.

MEYER, M. A retórica. Trad. Marly N. Peres. São Paulo: Ática, 2007.

RAUCHS, P. Du bon usage de la nostalgia. Paris: L'Harmattan, 2013.

MORAES, R. Morre Brilhante Ustra, ex-chefe do DOI-CODI durante a ditadura. G1. 15 outubro 2015. Disponível em: http://g1.globo.com/distrito-federal/noticia/2015/10/morre-brilhante-ustra-ex-chefe-de-orgao-derepressao-na-ditadura.html. Acesso em: 28 outubro 2021.

ROBIN, R. A memória saturada. Tradução de Cristiane Dias, Greciely Costa. Campinas, SP: Editora da Unicamp, 2016

SELIGMANN-SILVA, M. Apresentação da questão: a literatura do trauma. In: SELIGMANN-SILVA, Márcio (Org.). História, memória e literatura: o testemunho na era das catástrofes. Campinas, SP: Editora da Unicamp, 2003, p. 45-58.

SELIGMANN-SILVA, M. O testemunho: entre a ficção e o "real". In: SELIGMANN-SILVA, Márcio (Org.). História, memória e literatura: o testemunho na era das catástrofes. Campinas, SP: Editora da Unicamp, 2003, p. 371-385.

SELIGMANN-SILVA, M. Prefácio (Pierre Seel: um sobrevivente da dor e do silêncio). In: SEEL, Pierre. Eu, Pierre Seel, deportado homossexual. Trad. Tiago Elídio. Rio de Janeiro: Cassará, 2012.

VITALE, A. ¿Cómo pudo suceder? Prensa escrita y golpismo en la Argentina (1930-1976). Ciudad Autónoma de Buenos Aires: Eudeba, 2015. 